\title{
Comparison of Fluoride Levels (Total and Extracted) in Young, Old Tea Leaves and Market Tea Samples along with Impact of Tea Infusion on Dental Fluorosis in Fluoride Endemic Villages of Nalgonda District, India
}

\author{
Vakdevi Validandi, Gopalan Viswanathan and Arjun L Khandare* \\ Indian Council of Medical Research, India
}

Submission: February 15, 2019; Published: March 06, 2019

*Corresponding author: Arjun L Khandare, Scientist 'G' (Director Grade Scientist), Head, Department of Food Toxicology, National Institute of Nutrition, Indian Council of Medical Research, Jamai-Osmania PO, Hyderabad, Telangana, India

\begin{abstract}
Tea is one of the sources for elevating daily fluoride intake and responsible for high prevalence of fluorosis in fluoride endemic areas. Aim of the study was to assess fluoride exposure dose in children and adults from different tea samples (young, old leaves and commercial tea). Six each young and old tea leaves were collected from different tea gardens at Kaziranga National park in Assam, India. Seven commonly consumed commercial-branded tea samples were procured from local markets. Total and extractable fluoride levels were estimated in all the tea samples using fluoride ion selective electrode method. Prepared tea samples were also collected from road side tea shops of fluorosis endemic areas in Nalgonda district, Telangana for fluoride analysis and dose calculation. The results revealed that total and extractable fluoride levels in young tea leaves were comparatively lower than old tea leaves and commercial tea samples $(p<0.002)$. Fluoride exposure doses for children and adults were calculated and compared with the recommended safe fluoride level $0.05 \mathrm{mg} \mathrm{kg}-1 \mathrm{~d}-1$. Children were exposed significantly higher fluoride dose through tea than the adults $(\mathrm{p}<0.04)$. Consumption of prepared tea delivers fluoride exposure dose from $0.03 \mathrm{mg} \mathrm{kg}-1 \mathrm{~d}-1$ to $0.14 \mathrm{mg} \mathrm{kg}-1 \mathrm{~d}-1$ for children and $0.01 \mathrm{mg} \mathrm{kg}-1 \mathrm{~d}-1$ to $0.06 \mathrm{mg} \mathrm{kg}-1 \mathrm{~d}-1$ for adults. Fluoride exposure doses from milk added prepared teas were significantly lower than the other tea infusions from young, old tea leaves and commercial tea samples $(\mathrm{p}<0.02)$. The rate of prevalence of fluorosis increases with increase of fluoride exposure doses through tea $(\mathrm{p}<0.0001)$. Adopting the recommended good agricultural practices in tea cultivation and use of milk in tea preparation can reduces the excess fluoride burden and fluorosis risk through tea consumption in fluoride endemic areas.
\end{abstract}

Keywords: Tea; Fluoride exposure dose; Dental fluorosis; Children; Total fluoride, Extractable fluoride

\section{Introduction}

Exposure to excess fluoride through water and food is the primary reason for the prevalence of dental and skeletal fluorosis in various parts of the world [1]. Dental fluorosis is characterized by mottling of tooth surface or enamel; appearance of white horizontal striations on the tooth surface or opaque patches of chalky white discolorations. In moderate to severe forms of fluorosis, the opaque patches can become stained yellow to brown or even black. Eventually the increased tooth porosity leads to structural damages, such as pitting or chipping [2]. Skeletal fluorosis is a pathological condition that may arise from long-term exposure to elevated levels of fluoride. Symptoms of skeletal fluorosis include chronic joint pain; stiffness of the joints; calcification of ligaments and osteosclerosis of cancellous bone. Also, crippling skeletal fluorosis is associated with limited movement of the joints; skeletal deformities; intense calcification of ligaments; muscle wasting and neurological deficits [3,4]. Many previous studies reported a significant inverse-concentrationresponse relationship between the fluoride intake level and the Intelligence Quotient (IQ) of children. Excess fluoride intake can reduce the IQ and increase the rate of mental retardation [5]. The recommended safe fluoride intake through all sources is $0.01 \mathrm{mg}$ $\mathrm{kg}^{-1} \mathrm{~d}^{-1}$ for infants up to 6 months and $0.05-0.07 \mathrm{mgkg}^{-1} \mathrm{~d}^{-1}$ for all ages of above 6 months [6,7]. Apart from drinking water, tea is a popular and most widely consumed beverage. Consumption of 
tea can deliver many beneficial effects on human health [8]. It can protect against diseases that are associated with free radical damage including atherosclerosis, coronary heart disease and cancer [9]. However, consumption of tea in larger quantities expose higher amount of fluoride to the human population than the recommended level $[10,11]$. Fluoride levels in prepared tea samples reported from India; Tibet; China; and Ethiopia were ranged from $2 \mathrm{mgL}^{-1}$ to $524 \mathrm{mgL}^{-1}$ [12-17]. Many previous studies reported that the consumption of tea is a main reason for the prevalence of dental and skeletal fluorosis in various parts of world [18-20]. The tea plant (Camellia sinensis L.) is known to be a fluoride accumulator, which selectively accumulates fluoride from soil up to 20-30 times higher than that in other plants [21]. As the uptake of fluoride through roots of the tea plants is an active process and energy-dependent, tea plants can accumulate considerably more fluoride [22]. The mechanism behind this is different ion channel inhibitors in tea plants such as anionic and cationic channel inhibitors responsible for the absorption of fluoride from soil and translocation of fluoride into the whole tea plant [23]. Most of the fluoride absorbed in tea plants is in ionic forms. Soil $\mathrm{pH}$ and aluminum in soil influences the absorption and translocation of fluoride from roots to leaves [24]. Reports from the previous studies revealed that the tea leaves contain nearly 98\% fluoride in the whole plant and the most was accumulated in old leaves as it stays for longer time on the plant [21,25]. Fluorides from tea leaves are consistently leached into infusion upon heating. More than $75 \%$ of fluoride in tea leaves can be extracted through boiling in water [14]. Apart from fluoride in tea leaves, the usage of high fluoride water for tea processing and increase of brewing time also significantly elevates the fluoride concentration in final ready to consume tea infusion. This ultimately enhances the daily fluoride intake and fluoride burden through tea consumption in tea consuming population which will be additional burden in the fluoride endemic area [16,18-20]. The systemic fluoride absorption through the gastrointestinal tract into the bloodstream is nearly $100 \%$ by the process of simple diffusion [26]. In the fluorosis endemic areas, tea contributes an additional burden of fluoride exposure and increases the severity of fluorosis. Therefore, the present study was aimed to assess and compare the fluoride exposure dose levels from young, old tea leaves and various commercial tea samples with prepared teas collected from fluorosis endemic areas. This may be helpful to find out the quantitative contribution of tea on the prevalence of fluorosis as well as to find suitable factors to minimize daily fluoride exposure through tea as strategic plan in fluoride endemic areas.

\section{Materials and Methods}

\section{Collection of young, old tea leaves and commercial tea samples}

Six each young and old fresh tea leaves were collected randomly from six different tea gardens at Kaziranga National Park areas in Assam, India. Figure 1 shows the appearance of tea gardens and young and old tea leaves. The first two young leaves from the top and old tea leaves from bottom of the tea plants were collected and stored in properly labeled polyethylene bags. Then the labeled tea bags were transported to the laboratory in cold condition. Commonly used seven different branded-commercial tea samples were also procured from a local market for fluoride analysis.

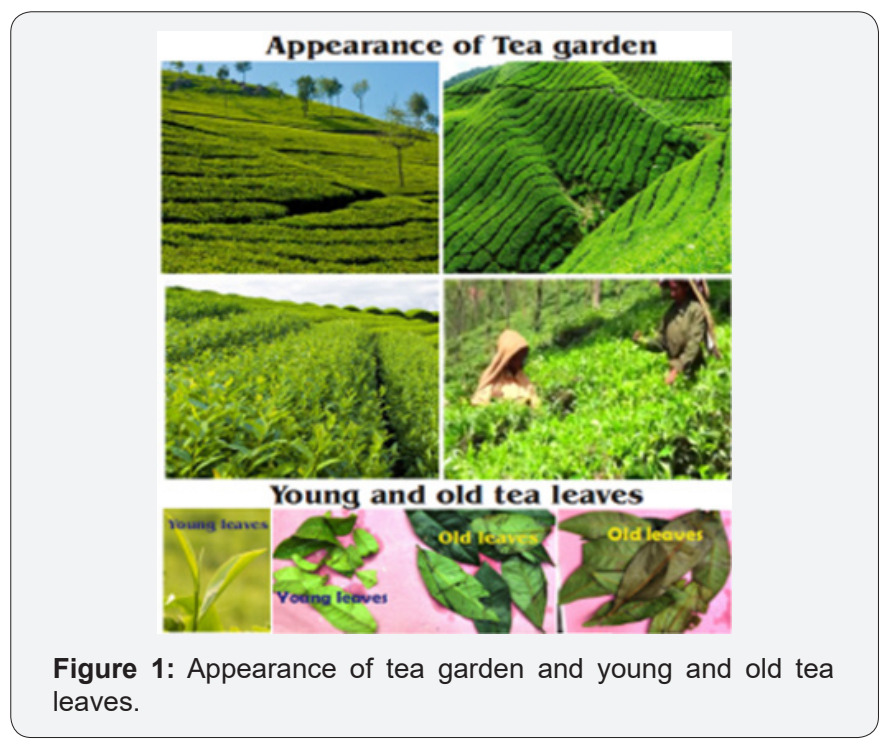

\section{Estimation of total fluoride level in tea samples}

Young and old tea leaves were thoroughly washed with distilled water and dried at $75^{\circ} \mathrm{C}$ for 6 hours. Then the dried tea leaves were chopped; powdered and sieved through $0.25 \mu \mathrm{m}$ sieve to obtain particle size $0.25 \mu \mathrm{m}$. Two grams of each was weighed (dried young and old tea leaves and commercial tea samples) and they were reduced in to ash after keeping them in a muffle furnace at $600^{\circ} \mathrm{C}$ for 4 hours. The ash was dissolved in $5 \mathrm{ml} 0.5 \mathrm{M}$ perchloric acid and the excess acidity was neutralized by $0.5 \mathrm{M} \mathrm{NaOH}$ and followed by the addition of $0.5 \mathrm{M}$ sodium citrate buffer to maintain the $\mathrm{pH}$ level 6.5. The content was made up to $20 \mathrm{ml}$ and the fluoride level was estimated through Ion Selective Electrode method [14].

\section{Estimation of extractable fluoride level in tea samples}

One gram each of commercial tea samples and tea leaves (old and young) were separately taken in conical flask contains $80 \mathrm{~mL}$ Milli-Q distilled water. Then the content was kept in boiling water bath and brewed for 15 minutes. The solutions were cooled, filtered through muslin cloth and are made up to $100 \mathrm{~mL}$ with distilled water. Then the fluoride level in tea infusion was analyzed using fluoride Ion Selective Electrode method [27].

\section{Assessment of prevalence of fluorosis}

Prevalence of fluorosis in selected 12 fluoride endemic villages of Nalgonda district of Telangana, South India was assessed through clinical survey and expressed as percentage prevalence of fluorosis. Symptoms of dental and skeletal fluorosis were shown in Figure 2. The percentage prevalence of fluorosis was calculated from the number of people affected by fluorosis in the respective area with total number of people surveyed. Totally 1702 boys 
and 1384 girls aged between 8 to 13 years; 2350 male and 1999 female with the age group above 18 to 70 years were examined for this study.

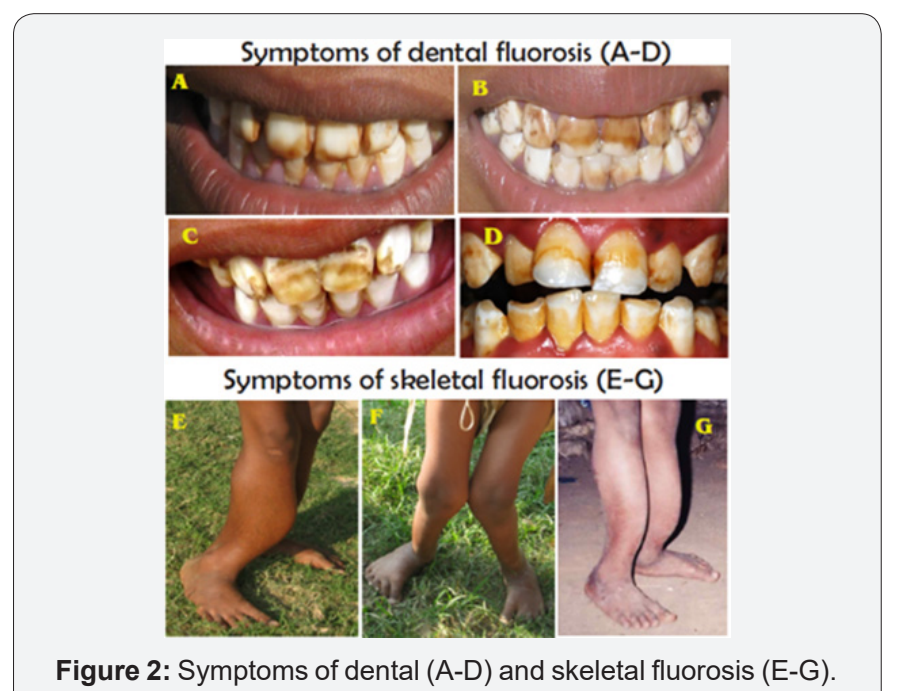

\section{Collection and analysis of water samples}

A total of 95 drinking water samples were collected from all corners and middle of the selected fluorosis endemic villages and the collected water samples were stored in clean, high density polyethylene bottles at $4^{\circ} \mathrm{C}$ till $\mathrm{F}$ analysis. Fluoride levels in drinking water samples were measured by using fluoride ion selective electrode.

\section{Collection and analysis of prepared tea samples}

A total of sixty milk-added ready to drink tea samples, (five each tea samples) were collected from the selected twelve fluorosis endemic villages and carefully packed in polyethylene bottles. Fluoride level in the tea samples was analyzed using fluoride ion analyzer.

\section{Estimation of fluoride exposure dose through tea consumption}

The fluoride exposure dose through tea consumption was calculated by the following formula

$$
\text { Flouride Exposure Dose }=\frac{(C \times V)}{B W}
$$

Where, $\mathrm{C}$ is the fluoride concentration $\left(\mathrm{mgL}^{-1}\right)$ in tea infusion, $\mathrm{V}$ is the volume of tea infusion consumed per day $(\mathrm{mL})$ and $\mathrm{BW}$ is the body weight $(\mathrm{kg})$. The tea infusion intake levels of different age groups were accounted through household surveys. The estimated tea infusion intake for children and adult was about $180 \mathrm{~mL}$ per day respectively. For calculation, body weight of children between the age group of 8 to 13 years was kept as $30 \mathrm{~kg}$. Also, the body weight of adults between the age group of 18 to 70 years was kept as $70 \mathrm{~kg}$.

\section{Statistical analysis}

Results are presented as means and standard deviations between the observed values. Relationships between total and extractable fluoride levels in young, old tea leaves and commercial tea samples were assessed through the statistical parameters such as correlation coefficient $(\mathrm{r})$; coefficient of determination $\left(\mathrm{r}^{2}\right)$; Fisher-ratio (F - ratio); linear regression; Student's t- test; Pearson correlation analysis and one-way ANOVA. Statistical analyses were performed by using SPSS statistical software package version 22.0. $\mathrm{P}<0.05$ was considered as statistically significant.

\section{Results}

\section{Total and extractable fluoride levels in various tea samples}

Table 1: Total and extractable fluoride levels in young, old tea leaves and commercial tea samples.

\begin{tabular}{|c|c|c|c|c|}
\hline $\begin{array}{c}\text { Sample } \\
\text { Type }\end{array}$ & $\mathbf{N}$ & $\begin{array}{c}\text { Total Fluo- } \\
\text { ride Level } \\
\mathbf{( m g ~ k g}^{-1} \mathbf{)}\end{array}$ & $\begin{array}{c}\text { Extractable } \\
\text { Fluoride } \\
\text { Level } \\
\mathbf{( m g ~ L}^{-1} \mathbf{)}\end{array}$ & $\begin{array}{c}\text { Level of } \\
\text { Extraction } \\
\mathbf{( \% )}\end{array}$ \\
\hline $\begin{array}{c}\text { Young tea } \\
\text { leaves }\end{array}$ & 6 & $\begin{array}{c}26.8 \pm 13.1 \\
(5.35)\end{array}$ & $\begin{array}{c}23.0 \pm 12.3 \\
(5.0)\end{array}$ & $84 \pm 9$ \\
\hline $\begin{array}{c}\text { Old tea } \\
\text { leaves }\end{array}$ & 6 & $\begin{array}{c}105 \pm 55.0 \\
(22.5)\end{array}$ & $\begin{array}{c}52.1 \pm 24.3 \\
(9.9)\end{array}$ & $51 \pm 6$ \\
\hline $\begin{array}{c}\text { Commercial } \\
\text { tea samples }\end{array}$ & 7 & $\begin{array}{c}38.3 \pm 12.1 \\
(4.5)\end{array}$ & $\begin{array}{c}34.8 \pm 10.4 \\
(3.9)\end{array}$ & $92 \pm 7$ \\
\hline
\end{tabular}

Results are represented as mean \pm standard deviation (Standard error)

Total fluoride levels in young tea leaves were ranged from $10 \mathrm{mgkg}^{-1}$ to $43 \mathrm{mgkg}^{-1}$ and extractable fluoride levels (in infusion) were ranged from $9 \mathrm{mgL}^{-1}$ to $39 \mathrm{mgL}^{-1}$. Whereas Ranges of total and extractable fluoride level in old tea leaves were from $49 \mathrm{mgkg}^{-1}$ to $200 \mathrm{mgkg}^{-1}$ and from $27 \mathrm{mgL}^{-1}$ to $96 \mathrm{mgL}^{-1}$, respectively. Leaching of fluoride from young tea leaves was 33\% higher than the old tea leaves. In general, more than $90 \%$ fluorides in commercial tea samples were extractable in water by boiling. Leaching of fluoride from commercial tea samples was significantly higher than young and old tea leaves $(\mathrm{p}<0.01)$. The ranges of the total and extractable fluoride levels in commercial tea samples were from $24 \mathrm{mgkg}^{-1}$ to $61 \mathrm{mgkg}^{-1}$ and from $22 \mathrm{mgL}^{-1}$ to $56 \mathrm{mgL}^{-1}$, respectively. Leaching of fluoride from commercial tea samples was $41 \%$ higher than older tea leaves. Extractable fluoride levels in old tea leaves were about 2.3 times and 1.5 times higher than the young tea leaves and commercial tea samples, respectively (Table 1 ). In addition, total fluoride levels in old tea leaves were about 3 and 4 times higher than the commercial tea samples and young tea leaves, respectively. Table 2 shows the correlation between total fluoride levels and extractable fluoride levels in young, old tea leaves and commercial tea samples. According to the student's $t$-test, total fluoride levels in young, old tea leaves and commercial tea samples were significantly higher than the fluoride levels of their infusions $(r>$ $0.9666, p<0.05$ ). It has been observed that, significant differences in total fluoride levels as well as extractable fluoride levels in young and old tea leaves (Table 3 ). In young and old tea leaves, 
there was a positive correlation between their total fluoride levels as well as extractable fluoride levels (Table 3). Moreover, there was no significant difference between the total fluoride levels of young tea leaves and commercial tea samples (Table 3). There was also no significant difference between extractable fluoride levels of young tea leaves with commercial tea samples. There was no significant difference between the extractable fluoride levels in old tea leaves with commercial tea samples. Pearson correlation analysis indicates a positive correlation between total fluoride levels of young tea leaves with commercial tea samples. Moreover, the same trend was observed in total fluoride levels of old tea leaves and commercial tea samples. A weak positive correlation was observed between extractable fluoride levels in young tea leaves with commercial tea samples. As well as the same trend was observed between the extractable fluoride levels of old tea leaves with commercial tea samples. Figure 3 shows the relationship between the fluoride levels of water and prepared tea collected from fluorosis endemic areas. Fluoride levels in prepared tea samples significantly increased with the increase of water fluoride level $(\mathrm{p}<0.01)$.

Table 2: Correlation between total fluoride levels $(\mathrm{Y})$ and extractable fluoride levels $(\mathrm{X})$ in young, old tea leaves and commercial tea samples.

\begin{tabular}{|c|c|c|c|c|}
\hline \multicolumn{2}{|c|}{ Statistical Analysis } & \multirow{2}{*}{$\begin{array}{c}\text { (Y) Vs }(\mathrm{X}) \text { in Young Tea Leaves } \\
4.5931 \\
\end{array}$} & \multirow{2}{*}{$\begin{array}{c}(\mathrm{Y}) \text { Vs }(\mathrm{X}) \text { in Old Tea Leaves } \\
4.1353\end{array}$} & \multirow{2}{*}{$\begin{array}{c}(\mathbf{Y}) \text { Vs }(\mathbf{X}) \\
\text { in Commercial Tea Sample } \\
2.8011 \\
\end{array}$} \\
\hline t toct (Poinod) & $t$ & & & \\
\hline & $\mathrm{p}$ & 0.0059 & 0.009 & 0.0311 \\
\hline One way ANOVA & F - ratio & 0.2713 & 4.7123 & 0.3419 \\
\hline \multicolumn{5}{|c|}{$\begin{array}{c}p \\
0.6138 \\
0.0551 \\
0.5696\end{array}$} \\
\hline \multirow{2}{*}{ Pearson correlation } & $\mathrm{r}$ & 0.9891 & 0.9805 & 0.9667 \\
\hline & $\mathrm{r}^{2}$ & 0.9783 & 0.9614 & 0.9345 \\
\hline \multicolumn{5}{|c|}{$\mathrm{p}<0.05$ was considered as statistically significant } \\
\hline
\end{tabular}

Table 3: Relationships between total and extractable fluoride levels of young (A), old tea leaves (B) and commercial tea samples (C).

\begin{tabular}{|c|c|c|c|c|c|c|c|}
\hline \multirow{2}{*}{\multicolumn{2}{|c|}{$\begin{array}{l}\text { Statistical Analysis } \\
\text { (A)Vs (B) }\end{array}$}} & \multicolumn{3}{|c|}{ Total Fluoride Level in } & \multicolumn{3}{|c|}{ Extractable Fluoride Level in } \\
\hline & & \multirow{2}{*}{$\begin{array}{c}\text { (A)Vs (C) } \\
-4.37\end{array}$} & \multirow{2}{*}{$\begin{array}{c}\text { (B)Vs (C) } \\
-1.73 \\
\end{array}$} & \multirow{2}{*}{$\begin{array}{c}\text { (A)Vs (B) } \\
3.31\end{array}$} & \multirow{2}{*}{$\begin{array}{c}\text { (A)Vs (C) } \\
-4.01 \\
\end{array}$} & \multirow{2}{*}{$\begin{array}{c}\text { (B)Vs (C) } \\
-1.67 \\
\end{array}$} & \multirow[b]{2}{*}{2.12} \\
\hline$t$ tect (Paired) & $t$ & & & & & & \\
\hline 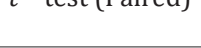 & $\mathrm{p}$ & 0.0072 & 0.1442 & 0.0213 & 0.0102 & 0.1566 & 0.0877 \\
\hline \multirow{2}{*}{ One way ANOVA } & F - ratio & 11.57 & 1.59 & 9.74 & 6.85 & 2.32 & 4.16 \\
\hline & $\mathrm{p}$ & 0.0068 & 0.2361 & 0.0109 & 0.0257 & 0.1584 & 0.0688 \\
\hline \multirow{2}{*}{$\begin{array}{l}\text { Pearson cor- } \\
\text { relation }\end{array}$} & $\mathrm{r}$ & 0.8759 & 0.5394 & 0.4079 & 0.7139 & 0.2204 & 0.1728 \\
\hline & $\mathrm{r}^{2}$ & 0.7672 & 0.291 & 0.1664 & 0.5097 & 0.0486 & 0.0299 \\
\hline Analysis & Result & $\begin{array}{l}\text { Strongly Pos- } \\
\text { itive }\end{array}$ & Weakly Positive & Weakly Positive & $\begin{array}{l}\text { Moderately } \\
\text { Positive }\end{array}$ & Weakly Positive & Weakly Positive \\
\hline \multicolumn{8}{|c|}{$\mathrm{p}<0.05$ was considered as statistically significant } \\
\hline
\end{tabular}

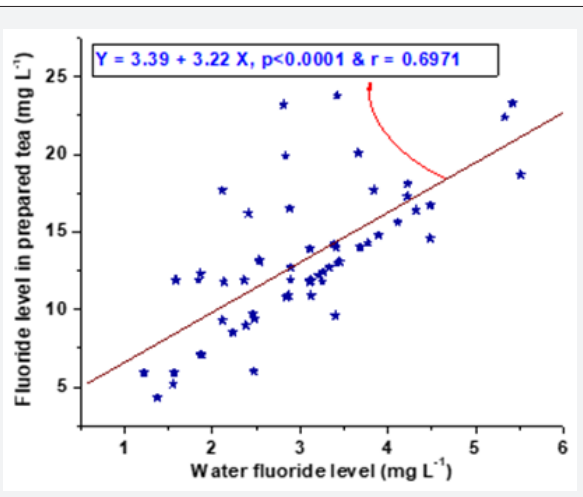

Figure 3: Relationship between fluoride levels of water and prepared tea from fluorosis endemic areas.

\section{Comparison of fluoride exposure doses from infusions of various tea samples with prepared tea from fluorosis endemic areas}

Mean fluoride exposure dose levels through infusions of young, old tea leaves, commercial tea samples and prepared tea were shown in Figure 4. Children were significantly exposed to more fluoride than the adults through tea consumption $(\mathrm{p}<0.04)$. Tea samples collected from fluorosis endemic areas supply less fluoride to children and adults than the tea infusions derived from young, old tea leaves and commercial tea samples (Figure 4). Table 4 illustrates the comparisons of mean fluoride exposure dose levels from infusions of young, old tea leaves, commercial tea samples with prepared tea. There was a significant difference in fluoride 
exposure dose levels for children and adults from infusions of young tea leaves and prepared tea $(\mathrm{p}<0.01)$. The range of fluoride exposure dose level through infusions of young tea leaves from $0.05 \mathrm{mgkg}^{-1} \mathrm{~d}^{-1}$ to $0.24 \mathrm{mg} \mathrm{kg}^{-1} \mathrm{~d}^{-1}$ for children and from $0.03 \mathrm{mg} \mathrm{kg}$ ${ }^{1} \mathrm{~d}^{-1}$ to $0.14 \mathrm{mg} \mathrm{kg}^{-1} \mathrm{~d}^{-1}$ for adults. Also, it has been observed that, significant differences between fluoride exposure dose levels through infusions of old tea leaves and commercial tea samples for children and adults (Table 4). The range of fluoride exposure dose through old tea leaves was from $0.16 \mathrm{mg} \mathrm{kg}^{-1} \mathrm{~d}^{-1}$ to $0.58 \mathrm{mg} \mathrm{kg}^{-1} \mathrm{~d}^{-1}$ for children and from $0.10 \mathrm{mg} \mathrm{kg}^{-1} \mathrm{~d}^{-1}$ to $0.35 \mathrm{mg} \mathrm{kg}^{-1} \mathrm{~d}^{-1}$ for adults, respectively. Moreover, tea infusions from commercial tea samples deliver fluoride exposure doses from the range of $0.13 \mathrm{mg} \mathrm{kg}^{-1} \mathrm{~d}^{-1}$ to $0.33 \mathrm{mg} \mathrm{kg}^{-1} \mathrm{~d}^{-1}$ for children and from $0.08 \mathrm{mg} \mathrm{kg}^{-1} \mathrm{~d}^{-1}$ to $0.20 \mathrm{mg} \mathrm{kg}$ ${ }^{1} \mathrm{~d}^{-1}$ for adults. Table 5 shows the comparison of fluoride exposure dose levels between children and adults through infusions of young, old tea leaves, commercial tea samples and prepared teas, respectively.

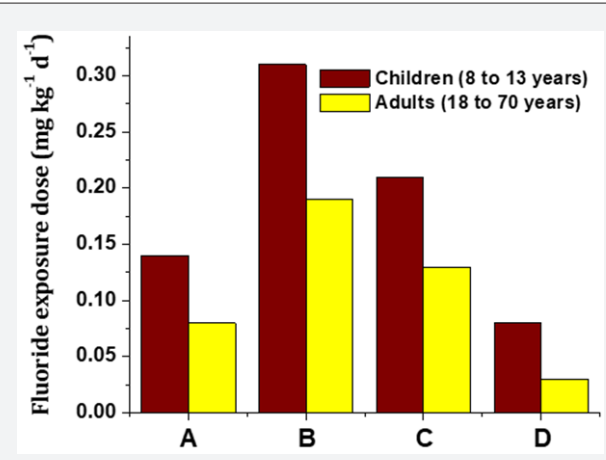

Figure 4: Mean fluoride exposure dose levels through young (A), old tea leaves (B), commercial tea samples (C) and prepared tea (D) for children and adults.

Table 4: One way ANOVA for comparison of fluoride exposure doses through infusions of young, old tea leaves and commercial tea samples with prepared tea from fluorosis endemic areas.

\begin{tabular}{|c|c|c|c|c|}
\hline \multirow{2}{*}{$\begin{array}{c}\text { Sample } \\
\text { Groups }\end{array}$} & \multicolumn{2}{|c|}{ Children } & \multicolumn{2}{c|}{ Adults } \\
\cline { 2 - 5 } & F - ratio & $\mathbf{p}$ & $\mathbf{F}$ - ratio & $\mathbf{p}$ \\
\hline $\begin{array}{c}\text { Young tea } \\
\text { leaves Vs } \\
\text { Prepared } \\
\text { tea }\end{array}$ & 16.75 & $<0.0001$ & 48.18 & $<0.0001$ \\
\hline $\begin{array}{c}\text { Old tea } \\
\text { leaves Vs } \\
\text { Prepared } \\
\text { tea }\end{array}$ & 124.74 & $<0.0001$ & 168.64 & $<0.0001$ \\
\hline $\begin{array}{c}\text { Commercial } \\
\text { tea samples } \\
\text { Vs Prepared } \\
\text { tea }\end{array}$ & 106.24 & $<0.0001$ & 198.55 & $<0.0001$ \\
\hline \multicolumn{4}{|c|}{$\mathrm{p}<0.05$ was considered as statistically significant } \\
\hline
\end{tabular}

Table 5: Comparison of fluoride exposure dose levels between children and adults through infusions of young, old tea leaves, commercial tea samples and prepared tea

\begin{tabular}{|l|l|l|}
\hline \multirow{2}{*}{ Sample Type } & \multicolumn{2}{|c|}{ Children Vs Adults } \\
\cline { 2 - 3 } & $\mathbf{t}$ & $\mathbf{p}$ \\
\hline
\end{tabular}

\begin{tabular}{|c|c|c|}
\hline Young tea leaves & 4.246 & $<0.01$ \\
\hline Old tea leaves & 5.198 & $<0.01$ \\
\hline $\begin{array}{c}\text { Commercial tea } \\
\text { samples }\end{array}$ & 9.142 & $<0.01$ \\
\hline Prepared tea & 23.14 & $<0.01$ \\
\hline
\end{tabular}

\section{Prevalence of fluorosis and fluoride exposure dose} levels through tea consumption

Nearly $88 \%$ groundwater samples from the study areas containing more than $2 \mathrm{mgL}^{-1}$ fluoride. The range of fluoride level in groundwater samples from fluorosis endemic areas was $1.12 \mathrm{mgL}$ ${ }^{1}$ and $6.5 \mathrm{mgL}^{-1}$ with the mean of $3.32 \mathrm{mgL}^{-1}$. Also, the fluoride levels in prepared tea samples were between $4.26 \mathrm{mgL}^{-1}$ and $23.81 \mathrm{mgL}^{-}$ ${ }^{1}$ with the mean of $13.16 \mathrm{mgL}^{-1}$. According to the clinical survey, there were $47 \%$ to $92 \%$ children and $50 \%$ to $91 \%$ adults affected by fluorosis in the selected endemic study areas (Table 6). Consumption of prepared tea can expose the children and adults to fluoride ranges from $0.03 \mathrm{mg} \mathrm{kg}^{-1} \mathrm{~d}^{-1}$ to $0.14 \mathrm{mgkg}^{-1} \mathrm{~d}^{-1}$ and $0.01 \mathrm{mgkg}$ ${ }^{1} \mathrm{~d}^{-1}$ to $0.06 \mathrm{mg} \mathrm{kg}^{-1} \mathrm{~d}^{-1}$, respectively (Table 7 ). According to Figure 5 , there was a significant increase in the rate of prevalence of fluorosis with the increase of fluoride exposure dose levels through tea consumption $(\mathrm{p}<0.01)$. Regression analysis indicates that the exposure of every $0.01 \mathrm{mgkg}^{-1} \mathrm{~d}^{-1}$ unit of fluoride exposure dose to children subsequently increases the rate of prevalence of fluorosis up to $7 \%$. Also, exposure of every $0.01 \mathrm{mgkg}^{-1} \mathrm{~d}^{-1}$ unit of fluoride exposure dose to adults through tea consumption successively increases the rate of prevalence of fluorosis up to $10 \%$ (Figure 5).

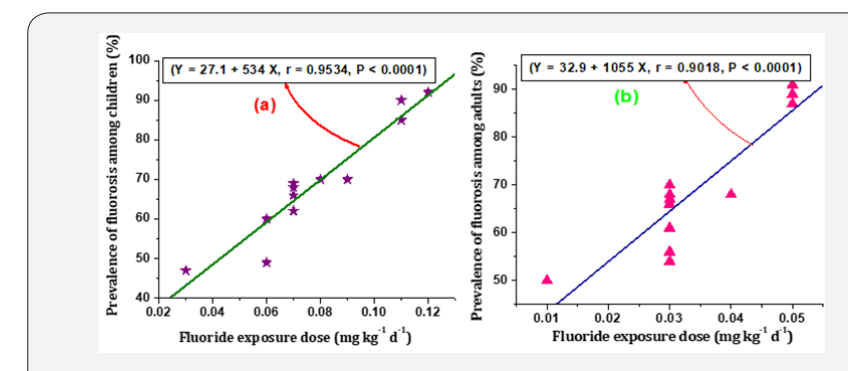

Figure 5: Relationships between fluoride exposure doses through prepared tea and prevalence of fluorosis among children (a) and adults (b) in fluorosis endemic areas.

Table 6: Prevalence of fluorosis in fluorosis endemic areas of Nalgonda district, Telangana.

\begin{tabular}{|c|c|c|c|c|c|c|}
\hline \multirow{2}{*}{ Areas } & \multicolumn{2}{|c|}{$\begin{array}{c}\text { Prevalence of Fluorosis } \\
\text { among Children }\end{array}$} & \multicolumn{2}{|c|}{$\begin{array}{c}\text { Prevalence of Fluorosis } \\
\text { among Adults }\end{array}$} \\
\cline { 2 - 7 } & $\begin{array}{c}\text { Sur- } \\
\text { veyed }\end{array}$ & $\begin{array}{c}\text { Affect- } \\
\text { ed }\end{array}$ & $\begin{array}{c}\text { Preva- } \\
\text { lence } \\
\text { of Flu- } \\
\text { orosis } \\
\text { (\%) }\end{array}$ & $\begin{array}{c}\text { Sur- } \\
\text { veyed }\end{array}$ & $\begin{array}{c}\text { Preva- } \\
\text { lence } \\
\text { Affect- } \\
\text { ed Flu- } \\
\text { orosis } \\
\text { (\%) }\end{array}$ \\
\hline Area 1 & 608 & 300 & 49 & 754 & 409 & 54 \\
\hline Area 2 & 404 & 372 & 92 & 476 & 432 & 91 \\
\hline Area 3 & 260 & 160 & 62 & 421 & 258 & 61 \\
\hline Area 4 & 185 & 167 & 90 & 255 & 228 & 89 \\
\hline Area 5 & 199 & 170 & 85 & 268 & 232 & 87 \\
\hline
\end{tabular}




\begin{tabular}{|c|c|c|c|c|c|c|}
\hline Area 6 & 279 & 195 & 70 & 437 & 294 & 67 \\
\hline Area 7 & 213 & 145 & 68 & 302 & 204 & 68 \\
\hline Area 8 & 116 & 70 & 60 & 211 & 118 & 56 \\
\hline Area 9 & 174 & 115 & 66 & 306 & 213 & 70 \\
\hline Area 10 & 154 & 72 & 47 & 195 & 98 & 50 \\
\hline Area 11 & 201 & 139 & 69 & 280 & 184 & 66 \\
\hline Area 12 & 293 & 205 & 70 & 444 & 300 & 68 \\
\hline
\end{tabular}

Table 7: Fluoride level in drinking water, prepared tea and fluoride exposure dose through prepared tea from fluorosis endemic areas.

\begin{tabular}{|c|c|c|c|c|}
\hline \multirow{2}{*}{$\begin{array}{l}\text { Name of } \\
\text { the Area }\end{array}$} & \multicolumn{2}{|c|}{ Fluoride Level $\left(\mathrm{mg} \mathrm{L}^{-1}\right)$} & \multicolumn{2}{|c|}{$\begin{array}{c}\text { Fluoride Exposure Dose } \\
\text { through prepared Tea } \\
\left(\mathrm{mg} \mathrm{kg}^{-1} \mathrm{~d}^{-1}\right)\end{array}$} \\
\hline & $\begin{array}{l}\text { Drinking } \\
\text { Water }\end{array}$ & $\begin{array}{c}\text { Prepared } \\
\text { Tea }\end{array}$ & Children & Adults \\
\hline Area 1 & $2.34 \pm 0.33$ & $10.1 \pm 1.3$ & $\begin{array}{l}0.06 \pm \\
0.008\end{array}$ & $\begin{array}{l}0.03 \pm \\
0.003\end{array}$ \\
\hline Area 2 & $4.81 \pm 1.12$ & $19.8 \pm 3.7$ & $\begin{array}{l}0.12 \pm \\
0.022\end{array}$ & $\begin{array}{l}0.05 \pm \\
0.010\end{array}$ \\
\hline Area 3 & $2.80 \pm 0.64$ & $11.1 \pm 2.8$ & $\begin{array}{l}0.07 \pm \\
0.017\end{array}$ & $\begin{array}{l}0.03 \pm \\
0.007\end{array}$ \\
\hline Area 4 & $4.35 \pm 1.12$ & $17.8 \pm 3.8$ & $\begin{array}{l}0.11 \pm \\
0.023\end{array}$ & $\begin{array}{l}0.05 \pm \\
0.010\end{array}$ \\
\hline Area 5 & $4.24 \pm 1.19$ & $18.7 \pm 2.6$ & $\begin{array}{l}0.11 \pm \\
0.016\end{array}$ & $\begin{array}{l}0.05 \pm \\
0.007\end{array}$ \\
\hline Area 6 & $3.42 \pm 0.74$ & $13.5 \pm 2.8$ & $\begin{array}{c}0.08 \pm \\
0.017\end{array}$ & $\begin{array}{l}0.03 \pm \\
0.007\end{array}$ \\
\hline Area 7 & $3.13 \pm 0.34$ & $11.9 \pm 1.4$ & $\begin{array}{l}0.07 \pm \\
0.008\end{array}$ & $\begin{array}{l}0.03 \pm \\
0.004\end{array}$ \\
\hline Area 8 & $2.50 \pm 0.62$ & $10.6 \pm 2.6$ & $\begin{array}{l}0.06 \pm \\
0.016\end{array}$ & $\begin{array}{l}0.03 \pm \\
0.007\end{array}$ \\
\hline Area 9 & $3.03 \pm 0.32$ & $11.5 \pm 1.4$ & $\begin{array}{l}0.07 \pm \\
0.008\end{array}$ & $\begin{array}{l}0.03 \pm \\
0.004\end{array}$ \\
\hline Area 10 & $1.44 \pm 0.25$ & $5.7 \pm 1.0$ & $\begin{array}{l}0.03 \pm \\
0.006\end{array}$ & $\begin{array}{l}0.01 \pm \\
0.003\end{array}$ \\
\hline Area 11 & $3.06 \pm 0.42$ & $12.3 \pm 0.8$ & $\begin{array}{l}0.07 \pm \\
0.005\end{array}$ & $\begin{array}{l}0.03 \pm \\
0.002\end{array}$ \\
\hline Area 12 & $3.68 \pm 0.52$ & $15.0 \pm 1.0$ & $\begin{array}{l}0.09 \pm \\
0.006\end{array}$ & $\begin{array}{l}0.04 \pm \\
0.003\end{array}$ \\
\hline
\end{tabular}

Results are represented as mean \pm standard deviation

\section{Discussion}

\section{Total and extractable fluoride levels in tea samples}

It has been found that, large quantities of fluoride were accumulated in tea leaves, especially in old tea leaves $(\geq 200 \mathrm{mg} \mathrm{Kg}$ ${ }^{1}$ ). Accumulation of fluoride in tea plants depends on $\mathrm{pH}$, fluoride and aluminum levels in soil. Moreover, nowadays fertilizers are widely used to boost the production of tea. Tea plants can readily absorb more fluoride from soil when it is fertilized with fluoride containing fertilizers [28]. Cryolite is one of the fluorides bearing mineral $\left(\mathrm{Na}_{3} \mathrm{AlF}_{6}\right.$, sodium hexafluoro aluminate) and it is widely used as pesticide in tea gardens in large scale. Large quantities of fluoride can be easily absorbed by the tea leaves through the usage of cryolite [29]. Therefore, good agricultural practices are much needed for cultivating tea plants regarding the usage of fluoride containing pesticides and fertilizers. This can be useful to maintain the soil quality and ultimately to reduce fluoride level in tea plants. Mostly young tea leaves were used for the manufacture of commercial tea samples [30]. In young tea leaves, the quantities of ionic and soluble forms of fluoride were higher than old tea leaves. In old tea leaves, fluoride were present as insoluble forms such as $\mathrm{AlF}_{3}, \mathrm{MgF}_{2}$ and $\mathrm{CaF}_{2}$ [31]. Leaching of fluoride from old tea leaves was significantly lower than young leaves and commercial tea samples $(p<0.06)$. Since, the high fluoride level in infusions of old tea leaves, common ion effect may prevent the further dissolution of fluoride from old tea leaves. Usage of high fluoride water for tea preparation ultimately increases the fluoride level of prepared tea. This ultimately enhances the fluoride intake through tea consumption $[32,33]$. Nearly $34 \%$ fluoride in prepared tea was derived from high fluoride water used for processing tea infusions in fluorosis endemic regions [16]. There was a considerable difference between the fluoride levels of infusions from young tea leaves and commercial tea samples. The same was observed in the earlier study also where the infusions directly prepared from tea leaves significantly lower than the infusions prepared from packaged tea samples [15]. Nowadays, Sulfuryl fluoride $\left(\mathrm{SO}_{2} \mathrm{~F}_{2}\right)$ gas is being used as fumigant in storage of tea packages which is the source of fluoride; it may diffuse into tea and it may be the reason for the additional fluoride level in infusions prepared from commercially packed tea samples. Hence, necessary modification is needed in storage/preservation of commercial tea.

\section{Influence of tea consumption on the prevalence of fluorosis and fluoride exposure}

According to the result, fluoride exposure dose levels through tea consumption were significantly decreased with increase of age $(p<0.01)$. Hence, children are more exposed to fluoride than adults. As the old tea leaves contain more fluoride, fluoride exposure doses from old tea leaves were two times higher than the other tea samples. Hence a great caution is needed to avoid the contamination of old tea leaves with commercial tea samples. However, the old tea leaves are not commonly used for commercial purposes; some of the black tea samples and low grade dust tea were used old tea leaves and commercially supplying with low cost for the preparation of tea [17]. Children were exposed to fluoride about three and four times higher than the recommended safe level of $0.05 \mathrm{mgkg}^{-1} \mathrm{~d}^{-1}$ through young tea leaves and commercial tea samples, respectively. Adults were exposed to fluoride about two and three times higher than the safe limit $\left(0.05 \mathrm{mgkg}^{-1} \mathrm{~d}^{-1}\right)$ from young and commercial tea samples, respectively. Hence, a great care must be taken to avoid the fluoride exposure into a hazardous level through tea consumption. Prepared tea samples from fluorosis endemic areas were containing less fluoride than the infusions of young, old tea leaves and commercial tea samples. Prepared teas from study areas deliver fluoride exposure dose from $0.03 \mathrm{mgkg}^{-1} \mathrm{~d}^{-1}$ to $0.14 \mathrm{mgkg}^{-1} \mathrm{~d}^{-1}$ and $0.01 \mathrm{mgkg}^{-1} \mathrm{~d}^{-1}$ to 


\section{Advances in Dentistry \& Oral Health}

$0.06 \mathrm{mgkg}^{-1} \mathrm{~d}^{-1}$ to the children and adults, respectively. In study villages, commonly tea infusions were processing by the addition of more than one third of milk with water. Normally, milk contains very low fluoride than water from high fluoride areas. Hence, the usage of milk instead of water for the preparation tea can minimize the fluoride level in prepared tea samples. Moreover, due to the presence of high calcium in milk, milk consumptions diminish the fluoride bioavailability through the gastrointestinal tract by $20-50 \%$ in human [34]. High calcium in milk can reacts with fluoride and leads to form insoluble calcium fluoride $\left(\mathrm{CaF}_{2}\right)$ in the gastrointestinal tract. Moreover, the rate of prevalence of fluorosis among the milk-consuming children is lower than that of non-milk consuming children [35]. Hence, the addition of milk with tea can reduce fluoride absorption and excess fluoride burden. However, the qualitative reduction in fluoride exposure dose levels by the addition of different volumes of milk during tea preparation was not performed in this study. In addition, previous studies recommended those infusions of leaves from some of the medicinal plants such as Aspalathus linearis (Rooibos); Cyclopiaspp (Honey bush); Psidiumguyava L., (Common guava); Menthapiperita (Mint); Punicagranatum L. (Pomegranate); and Ocimumtenuiflorum L. (Holy basil) are suggested as alternatives for tea. The recommended herbal infusions instead of tea were given the similar aroma like tea infusion. It was also suggested the above plant leaves have more medicinal properties and low fluoride content than the tea plant [36]. Hence the infusions prepared from the suggested plant leaves can deliver comparatively lesser fluoride than the tea infusions to the people in fluorosis endemic areas.

\section{Conclusion}

Young tea leaves contain low fluoride than the old tea leaves and commercial tea samples. However, leaching of fluoride from old tea leaves was significantly lower than young leaves and commercial tea samples. In addition, leaching of fluoride from commercial tea samples was higher than the young and old tea leaves. Consumption of prepared tea can deliver fluoride exposure dose from $0.03 \mathrm{mgkg}^{-1} \mathrm{~d}^{-1}$ to $0.14 \mathrm{mgkg}^{-1} \mathrm{~d}^{-1}$ and $0.01 \mathrm{mgkg}$ ${ }^{1} \mathrm{~d}^{-1}$ to $0.06 \mathrm{mgkg}^{-1} \mathrm{~d}^{-1}$ to the children and adults, respectively. Fluoride exposure dose levels through the consumption of prepared tea were considerably lesser than other teas. Hence, the consumption of milk-added tea and the usage of young tea leaves for tea preparation can reduce the fluoride level in tea infusions. Also, it has been recommended to use the suggested herbal tea alternatives instead of tea and processing of tea with low fluoride water in order to minimize fluoride intake through tea. Therefore, adopting the recommended practices for the preparation of tea can reduce daily fluoride exposure and minimizes fluorosis risks in fluoride endemic areas.

\section{Acknowledgements}

The authors thank the Director, National Institute of Nutrition, Indian Council of Medical Research, and Hyderabad for supporting the study.

\section{References}

1. WHO (2002) Environmental health criteria? 227 Fluorides. Geneva, $1-251$.

2. Aoba T, Fejerskov 0 (2002) Dental fluorosis: chemistry and biology. Crit Rev Oral Biol Med 13(2): 155-170.

3. Rao NCR (2003) Fluoride and environment-a review. In: Bunch MJV, et al. (Eds.) Proceedings of third international conference on environment and health. York University, Chennai, India.

4. Susheela AK (2003) Treatise on fluorosis. ( $2^{\text {nd }}$ edn), Fluorosis Research and Rural Development Foundation, Delhi, India.

5. Xiang Q, Liang Y, Chen L, Wang C, Chen B, et al. (2003) Effect of fluoride in drinking water on children's intelligence. Fluoride 36(2): 84-94.

6. Erdal S, Buchanan SN (2005) A quantitative look at fluorosis, fluoride exposure, and intake in children using a health risk assessment approach. Environ Health Persp 113(1): 111-117.

7. Food and Nutrition Board (1997) Institute of Medicine. Dietary Reference Intakes for calcium, phosphorus, magnesium, vitamin D and fluoride. Washington DC: National Academy Press.

8. Higdon JV, Frei B (2003) Tea catechins and polyphenols: Health effects, metabolism, and antioxidant function. Crit Rev Food Sci 43(1): 89-143.

9. Kohlmeier L, Weterings C, Steck S, Kok FJ (1997) Tea and cancer prevention: an evaluation of the epidemiologic literature. Nutr Cancer 27(1): 1-13.

10. Gašper Tavčar KA, Svet MP, Alenka K (2012) Fluoride in teas of different types and forms and the exposure of humans to fluoride with tea and diet. Food Chem 130(2): 286-290.

11. Whyte MP, Essmyer K, Gannon FH, Reinus WR (2005) Skeletal fluorosis and instant tea. Am J Med 118(1): 78-82.

12. Gulati P, Singh V, Gupta MK, Vaidya V, Dass S, et al. (1993) Studies on the leaching of fluoride in tea infusions. Sci Total Environ 138(1-3): 213- 222.

13. Cao J, Bai X, Zhao Y, Liu J, Zhou D, et al. (1996) The relationship of fluorosis and brick tea drinking in Chinese Tibetans. Environ Health Perspect 104(12): 1340-1343.

14. Fung KF, Zhang ZQ, Wong JWC, Wong MH (1999) Fluoride contents in tea and soil from tea plantations and the release of fluoride into tea liquor during infusion. Environ Pollu 104(2): 197-205.

15. Lung SCC, Candice SC, Hsiao PK, Chiang KM (2003) Fluoride concentrations in three types of commercially packed tea drinks in Taiwan. J Expo Sci Environ Epid 13(1): 66-73.

16. Viswanathan G, Gopalakrishnan S, Ilango SS. (2010) Assessment of water contribution on total fluoride intake of various age groups of people in fluoride endemic and non-endemic areas of Dindigul District, Tamil Nadu, South India. Water Res 44(20): 6186-6200.

17. Zerabruk S, Chandravanshi BS, Zewge F (2010) Fluoride in black and green tea (Camellia sinensis) infusions in Ethiopia: measurement and safety evaluation. Bull Chem Soc Ethiop 24(3): 327-338.

18. Montero J, Costa J, Bica I, Barrios R (2018) Caries and quality of life in portuguese adolescents: Impact of diet and behavioural risk factors. J Clin Exp Dent 10(3): e218-e223.

19. Till C, Green R, Grundy JG, Hornung R, Neufeld R, et al. (2018) Community Water Fluoridation and urinary Fluoride Concentrations in a National Sample of Pregnant Women in Canada. Environ Health Perspect 126(10): 107001.

20. Zhang R, Cheng L, Zhang T, Xu T, Li M, et al. (2018) Brick tea consumption is a risk factor for dental caries and dental fluorosis among 12-year-old Tibetan children in Ganzi. Environ Geochem Health. 
21. Lu Y, Guo WF, Yang XQ (2004) Fluoride content in tea and its relationship with tea quality. J Agri Food Chem 52(14): 4472-4476.

22. Zhang L, Li Q, Ma L, Ruan J (2013) Characterization of fluoride uptake by roots of tea plants (Camellia sinensis (L.) O. Kuntze). Plant soil 366(1-2): 659-669.

23. Xian-chen Z, Hong jian G, Zheng zhu Z, Xiao chun W (2013) Influences of different ion channel inhibitors on the absorption of fluoride in tea plants (Camellia sinesis L.). Plant Growth Reg 69(1): 99-106.

24. Gao HJ, Zhao Q, Zhang XC, Wan XC, Mao JD (2014) Localization of Fluoride and Aluminum in Subcellular Fractions of Tea Leaves and Roots. J Agri Food Chem 62(10): 2313-2319.

25. Wong MH, Fung KF, Carr HP (2003) Aluminium and fluoride contents of tea, with emphasis on brick tea and their health implications. Toxico Lett 137(1-2): 111-120.

26. Maguire A, Zohouri FV, Mathers JC, Steen IN, Hindmarch PN, et al. (2005) Bioavailability of fluoride in drinking water: a human experimental study. J Dent Res 84 (11): 989-993.

27. Mahvi AH, Zazoli MA, Younecian M, Esfandiari Y (2006) Fluoride content of Iranian black tea and tea liquor. Fluoride 39(4): 266-268.

28. Amanlou M, Nabati F, Azizian H, Farsam H (2009) Assessment of fluoride content and daily intake from different brands of tea bags in Iran. Res Pharmace Sci 3(2): 55-59.
29. Borah J (2011) Monitoring the fluoride concentration in the ground water of tea gardens and brick industry areas of Dibrugarh district, Assam, India. Int J Chem Sci 9(4): 1613-1618.

30. Panda H (2011) The Complete Book on Cultivation and Manufacture of Tea. Asia Pacific Business Press Inc, India, pp. 1-592.

31. Cai HM, Peng CY, Chen J, Hou RY, Gao HJ, et al. (2014) X-ray photoelectron spectroscopy surface analysis of fluoride stress in tea (Camellia sinensis L. O. Kuntze) leaves. J Flu Chem 158: 11-15.

32. Viswanathan G, Jaswanth A, Gopalakrishnan S, Siva ilango S (2009) Mapping of fluoride endemic areas and assessment of fluoride exposure. Sci Tot Envir 407(5): 1579-1587.

33. Viswanathan G, Jaswanth A, Gopalakrishnan S, Siva ilango S, Aditya G (2009) Determining the optimal fluoride concentration in drinking water for fluoride endemic regions in South India. Sci Tot Envir 407 (20): 5298-5307.

34. Whitford GM (1996) The metabolism and toxicity of fluoride. Monographs in Oral Science 12-15: 46-58.

35. Chen YX, Lin MQ, Xiao YD, Gan WM, Min D, et al. (1997) Nutrition survey in dental fluorosis affected areas. Fluoride 30: 77-80.

36. Giljanović J, Prkić A, Bralić M, Brkljača M. (2012) Determination of fluoride content in tea infusion by using fluoride Ion-selective electrode. Int J Electrochem Sci 7: 2918-2927.

\section{Your next submission with Juniper Publishers will reach you the below assets}

- Quality Editorial service

- Swift Peer Review

- Reprints availability

- E-prints Service

- Manuscript Podcast for convenient understanding

- Global attainment for your research

- Manuscript accessibility in different formats

( Pdf, E-pub, Full Text, Audio)

- Unceasing customer service

Track the below URL for one-step submission

https://juniperpublishers.com/online-submission.php 